sector operators will also have to factor in developments under the Consumer Rights Directive. Article 19 of the Directive states:

Member States shall prohibit traders from charging consumers, in respect of the use of a given means of payment, fees that exceed the cost borne by the trader for the use of such means.

Assuming the Directive is approved by the Council of Ministers when they vote on it this month (July 2011), this means that payment card surcharges will be limited to no more than passing on the actual cost to the trader: no element of mark-up will be permitted. It is currently proposed that the Directive would require transposition into local member states' laws by the end of 2013.

In the meantime, expect yet more small print disclosure in advertisements, along the lines 'Credit card surcharge applies', and widespread adoption of 'Payment method charges' sections within traders' websites.

Nick Johnson, Partner, Osborne Clarke, London

E-mail: nick.johnson@osborneclarke.com

\title{
Subjective redundancy selection criteria can be OK for 'creative' roles
}

\section{Christopher Stack and Jenny Wotherspoon}

Journal of Direct, Data and Digital Marketing Practice (2011) 13, 170-173. doi:10.1057/dddmp.2011.35

Topic: Discrimination

Who: Mr P Lancaster v TBWA Manchester

Where: Employment Tribunal

When: Judgment handed down on 14 June 2011

\section{What happened}

\section{Background}

Mr Lancaster was employed by TBWA Manchester, a marketing and advertising agency, as a Senior Art Director from 24 February 2003 until 13 May 2009 when he was dismissed for redundancy at the age of 50. He suffered from a panic and social anxiety disorder, which amounted to a disability for the purposes of the Disability Discrimination Act 1995 (DDA 1995).

Like most businesses, TBWA Manchester was affected by the global economic crisis and, in particular, the account on which Mr Lancaster 


\section{TBWA's redundancy} criteria

\section{Disability provisions}

The verdict ... worked was put on hold meaning that a number of roles were placed at risk of redundancy. The Senior Art Director role was affected and

Mr Lancaster was placed in a redundancy selection pool with two other Senior Art Directors.

They were each assessed against a range of redundancy selection criteria, including three criteria that focused on communication skills as follows:

1. ability to perform as a team player;

2. influence on performance and attitude to others; and

3. actively participating in company activities and improving the organization's creative output (collectively the 'Communication Criteria').

Mr Lancaster was selected for redundancy and brought an Employment Tribunal claim for disability discrimination on the basis that the Communication Criteria placed him at a substantial disadvantage because of his disability and that it would have been a reasonable adjustment to remove the Communication Criteria. In the alternative he argued that all of the redundancy selection criteria used, which were subjective, placed him at a substantial disadvantage and that it would have been a reasonable adjustment to replace them in their entirety with objective criteria.

Mr Lancaster also brought claims for age discrimination, on the basis that he was 50 at the time of his dismissal, and for unfair dismissal.

\section{The legal position}

Under the DDA 1995 if an employer has any provision, criterion or practice (PCP) that places disabled employees at a substantial disadvantage, then that employer has a duty to make reasonable adjustments to prevent that disadvantage. When considering what constitutes a reasonable adjustment, one of the factors the employer should have regard to is whether or not making a particular adjustment would prevent the disadvantage suffered by the employee.

While Mr Lancaster's claim was considered in accordance with the DDA 1995, the Equality Act 2010 essentially replicates the same position. Therefore, the decision is still relevant for employers.

\section{The Employment Tribunal's decision}

When Mr Lancaster's claim was considered by the Employment Tribunal at first instance, it was found that:

- the Communication Criteria placed Mr Lancaster at a lower score than others in the pool and resulted in his redundancy;

- however, if the scores relating to the Communication Criteria were removed from the total scores given to the three Senior Art Directors in the redundancy selection pool, the result would have been the same: Mr Lancaster would still have received the lowest score and would have been selected for redundancy. Therefore, adjusting the criteria would not have removed the disadvantage faced by Mr Lancaster; 
- there was no evidence to suggest that replacing all of the redundancy selection criteria with objective criteria, such as length of service, disciplinary record or sickness record, would have prevented Mr Lancaster from being selected for redundancy; therefore, this was also not a reasonable adjustment either;

- it is dangerous for an employer to use wholly subjective redundancy selection criteria. However, the Tribunal found that it is for employers to determine their own selection criteria and the position at risk was a senior-level creative position, therefore purely objective criteria might not have been sufficient in these circumstances;

- a witness had been called who gave evidence that the advertising agency was inherently 'ageist'. However, there were no grounds to find or infer age discrimination from this suggestion. The two other candidates in the pool were of a similar age in their late forties and there was no suggestion that Mr Lancaster had been treated less favourably;

- TBWA Manchester had not properly consulted with Mr Lancaster about his redundancy and had only made limited, if any, efforts to seek alternative work for him, thus leading to a finding of unfair dismissal on procedural grounds. However, genuine and meaningful consultation would only have taken 4 weeks from the date of dismissal, therefore compensation was limited to 4 weeks.

... and the appeal

Lessons

\section{The Employment Appeal Tribunal's (EAT) decision}

The EAT agreed with the original decision of the Employment Tribunal and concluded that it had not erred in finding that there was neither disability nor age discrimination. In respect of unfair dismissal, it considered the Tribunal failed to assess whether, if there had been proper consultation, Mr Lancaster would have been offered and accepted alternative employment, therefore the case was remitted to the Tribunal to consider whether the compensatory award should have been increased.

\section{Actions for employers}

- Employers are at liberty to choose the redundancy selection criteria that they consider are fair and appropriate in any given circumstances. However, Mr P Lancaster v TBWA Manchester serves as a useful reminder that employers must consider whether any of the criteria are discriminatory and, in the case of disability discrimination, whether the criteria will need to be amended as a reasonable adjustment to prevent a disabled employee from suffering a substantial disadvantage.

- However, the fact that an adjustment gives an employee 'a chance' to avoid redundancy will not necessarily make the adjustment reasonable. The fundamental question is whether the adjustment would prevent the substantial disadvantage and this will need to be decided on the facts of each case. 
- In most cases, employers should ensure that redundancy criteria are objective in nature. However, in some cases the Tribunal may be prepared to accept some subjective criteria (alongside objective criteria) where the role is creative in nature and not easily assessed against objective factors.

- In addition, Mr P Lancaster v TBWA Manchester highlights the importance of following a fair redundancy procedure including genuine and meaningful consultation with an employee about alternatives to redundancy and considering any suitable alternative employment.

Christopher Stack, Solicitor, Osborne Clarke, London

E-mail: christopher.stack@ osborneclarke.com

Jenny Wotherspoon, Senior Associate, Osborne Clarke, London E-mail:jenny.wotherspoon@osborneclarke.com

\section{Was Swedish ad an 'invitation to purchase'?}

\section{Manana Shrimpling}

Journal of Direct, Data and Digital Marketing Practice (2011) 13, 173-175. doi:10.1057/dddmp.2011.36

Topic: Consumer protection

Who: Ving Sverige AB

Where: Court of Justice of the EU

When: 12 May 2011

Law as stated at: 7 July 2011

Unfair Commercial Practices Directive

\section{What happened}

The Court of Justice of the European Union ('ECJ') ruled on the meaning of 'invitation to purchase' under the Unfair Commercial Practices Directive ('Directive'), which is wider than previously assumed in the UK, and clarified what mandatory material information the Directive requires a trader to provide to a consumer when making an invitation to purchase.

\section{Reference to ECJ}

The Swedish consumer ombudsman took action against Ving Sverige AB ('Ving') following an advertisement by Ving in a Swedish newspaper offering trips to New York. The advertisement contained the following wording in bold 'New York from SEK 7 820', and below that in smaller letters 'Flight from Arlanda with British Airways and 2 nights in the Bedford Hotel - Price per person in double room including airport taxes. Extra nights from SEK 1 320. Applies to 